\title{
SATISFACTION OF INDIVIDUAL TAXPAYERS' IN BANGLADESH
}

\author{
Dr. Shameem Ahmed \\ Associate Professor in Marketing \\ Visiting \& Part-Time at University Level \\ Dhaka, Bangladesh \\ E-mail: shameem.ahmed.phd.jnu@gmail.com \\ Md. Mahadi Masud Faisal \\ Deputy Commissioner of Tax \\ National Board of Revenue \\ Dhaka, Bangladesh
}

\begin{abstract}
As a developing country revenue is necessary to accelerate the economic growth of Bangladesh. Besides, implementation of the tax law, individual taxpayers' satisfaction will accelerate the collection of tax. The main objective of the study is to find out the impact of some determinants or factors which influence the overall satisfaction of the individual taxpayers' of Bangladesh. In this study, quantitative data was gathered by taking personal interviews among 450 respondents and the response rate was 93.33\%. Empirical tests using factor analysis and tests of hypothesis were performed in the study. The study incorporated three factors: tax rate, taxpaying system, and the behavior of tax employees. These three factors are considered to play a significant role in individual taxpayer satisfaction in Bangladesh. All the variables showed a significant and positive relationship between the independent variables and the dependent variable, taxpayers' satisfaction. The study suggests some recommendations in order to increase the effectiveness of the tax collection rate by satisfying individual taxpayers'.
\end{abstract}

Keywords: Tax, Individual Taxpayers', Satisfaction, Bangladesh.

JEL Classification Codes: H24.

\section{INTRODUCTION}

Taxation is necessary to fund public amenities and move a country's economy forward. The primary source of government revenue is taxation. Taxation plays a significant role in shaping the state-citizen relationship (Carnahan, 2015). Someone even claims that the state-taxpayer connection is a fiduciary relationship (Mahmood, 2018). While affluent countries have been able to raise much-needed cash for citizen welfare and development projects, developing countries such as Bangladesh have made remarkable progress in recent years. Besley and Persson (2013) state, as states activities expands, it not only increasing taxation amounts but also undergo significant changes in taxation patterns, with a greater emphasis on broader tax bases. Some taxes, particularly trade taxes, are becoming less important. Thus, in the industrialized world, 
income and value-added taxes do the heavy lifting in terms of producing enough revenue to finance the state's productive and redistributive functions.

In most low and lower-middle-income nations, tax collection has increased during the last decade, both in raw numbers and as a percentage of GDP. The economy of Bangladesh is very attractive for foreign investment because of its depth and diversity, which has turned its market into a frontier market. Bangladesh is the $8^{\text {th }}$ most populous country in the world and in 2019 it had a growth rate of $8 \%$ more than India and China. Its economic growth rate is on average $6 \%$ over the last decade. HSBC predicted it would be the biggest mover in the global GDP ranking by 2030 , moving from $42^{\text {th }}$ to $26^{\text {th }}$. Considering all the circumstances, Bangladesh has to make substantial progress in tax collection, overcoming all of its challenges, and formulating new policies for developing all of its sectors.

\section{STATEMENT OF PROBLEM}

Bangladesh is a developing country and its sustainable economic growth helps it to become a middle-income country in the world due to various policy implications by the current government. Economic growth is ensured by proper government expenditure and satisfactory revenue policy. Most of the revenue of the country generates from taxes. The National Board of Revenue (NBR) is the sole organization to collect taxes on behalf of the government from citizens of the country. To collect taxes, NBR formulates different policies, rules, and regulations. The performance of NBR is vital for the development of this country. To perform accurately, NBR has to focus on taxpayer satisfaction. In this study, the researchers incorporated the concept of individual taxpayers' satisfaction. Different policies, rules and regulations can be imposed regarding taxes, but most citizens are not interested in obeying them. In this situation, it would be beneficial and fruitful for NBR if it focuses on those factors properly which lead to individual taxpayers' satisfaction. In this study, attempts have been made to formulate a model of individual taxpayers' satisfaction by considering four factors in this regard.

\section{RESEARCH QUESTIONS}

In light of the problem statement, some specific questions have been raised and the researchers will try to answer the following questions throughout the research.

- Does the relationship between some independent variables and their consequences demonstrate strong outcomes, such as individual taxpayers' satisfaction in Bangladesh?

- Is it a positive or negative relationship?

\section{OBJECTIVES OF THE STUDY}

The specific objective of the study is:

- To test a previously developed model including new construct in the context of Bangladesh.

- To identify the impact of relevant constructs related to tax on individual taxpayer satisfaction.

- To identify whether there is a positive or negative relationship between variables.

- To recommend suggestions to overcome any problems that may exist in individual taxpayers' satisfaction. 


\section{LITERATURE REVIEW}

Over the past few years, taxation has been an important topic of discussion among practitioners and academicians. To accelerate and formulate the study's model, relevant literature has been link up bellow.

\section{Tax rate-individual taxpayers' satisfaction}

The tax rate is a vital factor in bringing motivation to individual taxpayers' (Padovano \& Galli, 2001). Human needs, wants, and demands are always high compared to their income, and excess money is not available to pay income tax for some taxpayers' (Deyganto, 2018). So, he suggested a lower tax rate for developing countries. The Tax rebate encourages taxpayers' to pay tax in time (Ibrahim et al., 2015).

\section{Taxpaying system- individual taxpayers' satisfaction}

A better taxpaying system encourages taxpayers' to pay tax (Ibrahim et al., 2015). On the other hand, (Adeyemi, 2013) showed, people are so busy in this modern age and don't like to face a time-consuming system or any other problems with paying tax. Except for a few taxpayers', most people are psychologically dissatisfied because taxes reduce their monetary income (Palil, 2010). So, psychological motivation is necessary in the taxpaying system.

\section{Behavior of tax employee- individual taxpayers' satisfaction}

Organizational behavior teaches to respect their clients (Luthans, 2002). Sales of every business increases by good behavior with clients, collection of income tax is no exception in this case (Ibrahim et al., 2015). In this regard all tax employee can behave positively with personal income taxpayers' (Wright, 2003).

\section{RESEARCH GAP}

The above discussion regarding individual taxpayers' satisfaction enables the researcher to write the research gap for the study. The gap in this study is as follows.

Gap 1: Since the previous research does not show behavioral factors of tax employees, it could be another factor of individual taxpayers' satisfaction. Behavioral factors will fulfill the theoretical or knowledge gap in the study. Findings of this research will differ from those of previous research due to the inclusion of new factors.

Gap 2: No model-based research has yet been found in Bangladesh. So, this research will cover the context gap.

\section{HYPOTHESIS OF THE STUDY}

In order to give effect to the objectives of the study, based on the introduction and literature review, some hypotheses have been constructed. Hypotheses have been constructed to determine whether relationships exist between independent and dependent variables, which have been shown below.

$\mathrm{H}_{1}$ : Tax rates have a positive and significant impact on individual taxpayers' satisfaction in Bangladesh.

$\mathrm{H}_{2}$ : The taxpaying system has a positive and significant impact on individual taxpayers' satisfaction in Bangladesh. 
$\mathrm{H}_{3}$ : The behavior of tax employees has a positive and significant impact on individual taxpayers' satisfaction in Bangladesh.

\section{CONCEPTUAL FRAMEWORK}

A conceptual framework has been designed in the study in order to define the factors that influence individual taxpayers' satisfaction. The primary purpose of the framework is to analyze the effect of tax rate, taxpaying system and behavior of employee on taxpayers' satisfaction. The conceptual framework of the study is as follows:

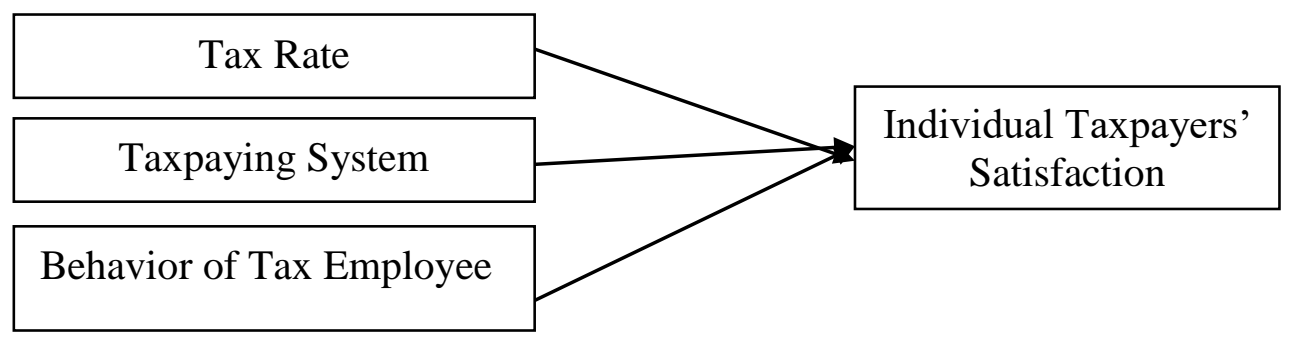

Figure 1. Research Framework

Source: Developed by Researcher, 2021

\section{METHODOLOGY}

The strategy for this research is based on a survey. A structured questionnaire was prepared for data collection. The researchers collected primary data through a survey of individual taxpayers' in Dhaka city in Bangladesh. In this regard, a simple random sampling technique was adopted in this study. The target population for this study would be all individual taxpayers' in Dhaka, Bangladesh. A pilot study was conducted with a sample of 50 respondents. Based on the pilot study, a minor alternation was made in the questionnaire. A total of 450 taxpayers' have been taken as a sample for this study. Data has been collected from $1^{\text {st }}$ February 2021 to $30^{\text {th }}$ May 2021 (four months). The exogenous variables of this study are the tax rate (TXR), the taxpaying system (TPS), and the behavior of tax employees (BTE). The indigenous variable is individual taxpayers' satisfaction. The questionnaire includes the respondent's demographic background, 14 preliminary measures for the construct. Minor alternations were made to the estimation scales to guarantee reasonableness for the setting. The designated constructs were rated on the 7-point Likert Scale. Empirical tests using factor analysis and tests of hypothesis were performed. In this regard, SPSS (version-25) was used to analyze the data collected from field-level interviews.

\section{DATA ANALYSIS}

The sample size of the survey was 450 and an error-free questionnaire was finally selected for 420 through face-to-face data collection. Four hundred twenty respondent's data was entered into SPSS version-25 for analysis. After data entry, missing values were checked and no missing values were found, but 20 respondents were excluded from the study due to outlier problems which prevented further processing of the data into SPSS. Finally, $(420-20)=400$ respondents' data has been considered for analysis of the study. The analysis section of the study consists of the demographic profile of the respondents, factor analysis, and multiple regression analysis. 


\section{Demographic Profile}

The demographic profile of the study is presented in the table below.

Table 1. Respondent Demographic Profile.

\begin{tabular}{|ll|c|c|}
\hline \multicolumn{1}{|c|}{ Variables } & Frequency & Percentage \\
\hline Gender & Male & 315 & 78.75 \\
& Female & 85 & 21.25 \\
Total & & $\mathbf{4 0 0}$ & $\mathbf{1 0 0}$ \\
\hline Age & & & \\
& $21-30$ & 38 & 9.5 \\
& $31-40$ & 84 & 21 \\
& $41-50$ & 128 & 32 \\
& 51-60 & 114 & 28.5 \\
Total & 61-Above & 36 & 9 \\
\hline Education & & $\mathbf{4 0 0}$ & $\mathbf{1 0 0}$ \\
& Under-Graduate & 83 & 20.75 \\
& Graduate & 206 & 51.50 \\
Total & Post Graduate & 111 & 27.75 \\
\hline
\end{tabular}

Source: Field data 2021

The respondents were $78.75 \%$ male and $21.25 \%$ female. Male respondents are higher than females because more male in involve in jobs and business than females. The age group of participants shows that $9.5 \%$ aged between $21-30,21 \%$ aged between $31-40,32 \%$ aged between $41-50,28.5 \%$ aged between 51-60, and 9\% aged between 61-above. The result shows that the majority of the respondents lie in the age group between 41-50 years old. The education level of respondents showed that $20.75 \%$ are at the undergraduate level, $51.50 \%$ of the respondents completed graduate level, whereas only $27.75 \%$ completed the post-graduate level.

\section{Exploratory Factor Analysis}

Exploratory factor analysis of the study has been provided in the following tables and necessary explanation also presented.

Table 2. KMO and Bartlett's Test

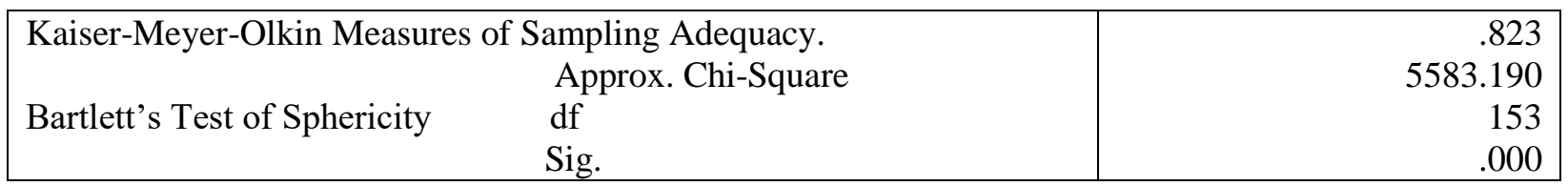

Through the main component analysis, the exploratory factor analysis was used to determine the item that is applied to a given component. In order to evaluate the data for factor analysis, the Bartlett test and Kaiser-Meyer-Oklin (KMO) were used. The value of the (KMO) test is 0.823, which is higher than the threshold of 0.60 (Cerny \& Kaiser, 1977). Bertlet's 
sphericity test is significant at (Chi-square $=5583.190, \mathrm{df}=153$ and $\mathrm{P}=0.000)$. This means the data is solid enough to move forward with the factor analysis.

Table 3. Constructs, Its Items, Loading, Cronbachs alpha, Mean and Standard Deviation.

\begin{tabular}{|c|c|c|c|c|c|c|}
\hline Constructs & Code & Items & $\begin{array}{c}\text { Items } \\
\text { Loading }\end{array}$ & $@$ & Mean & SD \\
\hline \multirow{3}{*}{ Tax Rate } & TAX 1 & The tax rate is reasonable for you. & .781 & \multirow{3}{*}{.88} & 6.07 & 1.468 \\
\hline & TAX 2 & The tax rate should be reduced. & .834 & & 5.55 & 1.489 \\
\hline & TAX 3 & You are getting tax rebate. & .894 & & 5.52 & 1.462 \\
\hline \multirow{4}{*}{$\begin{array}{l}\text { Taxpaying } \\
\text { System }\end{array}$} & TPS 1 & $\begin{array}{l}\text { Tax payment time is appropriate for } \\
\text { you. }\end{array}$ & .777 & \multirow{4}{*}{.83} & 3.71 & 2.583 \\
\hline & TPS 2 & $\begin{array}{l}\text { You support the online tax payment } \\
\text { system. }\end{array}$ & .901 & & 3.71 & 2.459 \\
\hline & TPS 3 & $\begin{array}{l}\text { You support the manual tax payment } \\
\text { system. }\end{array}$ & .843 & & 3.17 & 1.747 \\
\hline & TPS 4 & You face a problem when paying tax. & .765 & & 4.93 & 1.997 \\
\hline \multirow{3}{*}{$\begin{array}{l}\text { Behavior of } \\
\text { Tax } \\
\text { Employee }\end{array}$} & BTE 1 & $\begin{array}{l}\text { The behavior of tax employees is } \\
\text { satisfactory. }\end{array}$ & .877 & \multirow{3}{*}{.85} & 5.67 & 1.561 \\
\hline & BTE 2 & $\begin{array}{l}\text { The behavior of tax employees should } \\
\text { be improved. }\end{array}$ & .856 & & 6.25 & 1.132 \\
\hline & BTE 3 & $\begin{array}{l}\text { Non-satisfactory behavior of tax } \\
\text { employees discourages tax payers } \\
\text { from paying tax. }\end{array}$ & .912 & & 6.02 & 1.362 \\
\hline \multirow{4}{*}{$\begin{array}{l}\text { Individual } \\
\text { Taxpayers' } \\
\text { Satisfaction }\end{array}$} & IPS 1 & $\begin{array}{l}\text { You are satisfied with the overall } \\
\text { individual tax system in Bangladesh. }\end{array}$ & .790 & \multirow{4}{*}{.89} & 6.07 & 1.342 \\
\hline & IPS 2 & $\begin{array}{l}\text { Your satisfaction is increasing day by } \\
\text { day. }\end{array}$ & .880 & & 6.14 & 1.376 \\
\hline & IPS 3 & Your satisfaction never deteriorates. & .832 & & 6.15 & 1.060 \\
\hline & IPS 4 & $\begin{array}{l}\text { You share your satisfaction or } \\
\text { dissatisfaction with other individual } \\
\text { taxpayers. }\end{array}$ & .723 & & 6.09 & 1.041 \\
\hline
\end{tabular}

To assess for applicability, the 14 items were subjected to principal component analysis with varimax rotation. The results show that the 14 questions scored higher than 0.50 , as indicated by Hair et al. (2010). As a result, four components with eigenvalues greater than one emerged from the 14 elements. The tax rate has an eigenvalue of (4.612), the taxpaying system has an eigenvalue of (3.162), and the behavior of a tax employee has an eigenvalue of (2.123). The individual taxpayers' satisfaction eigenvalue is (1.132).

The reliability measures mean values ranged from 3.17 to 6.15 , indicating that the respondents had a high level of agreement with the variable. The respondents agreed with all of the statements in the construct on average. While there appears to be a reasonable range of responses based on the standard deviation, the score in the table varies from 1.041 to 2.583 in total. 


\section{Multiple Regression Analysis}

Multiple regression analysis was done to see if the independent factors have any effect on the satisfaction of individual taxpayers' (dependent factor). Each of the component scores (beta coefficients) of the independent factors has been regressed against the dependent variable (individual taxpayers' satisfaction). The dependent variable (individual taxpayers' satisfaction) was utilized as a proxy for respondents' assessments of individual taxpayers' satisfaction in Dhaka, Bangladesh. The regression analysis findings are presented in Tables 4, 5, and 6. The multiple correlation coefficients $(\mathrm{R})$, coefficient of determination or square multiple correlation coefficients $(\mathrm{R})$, adjusted $\mathrm{R}^{2}, \mathrm{~F}$ ratio with significance were investigated to forecast the regression model's goodness-of-fit.

Table 4. Model Summary

\begin{tabular}{|c|c|c|c|c|}
\hline Model & $\mathrm{R}$ & R Square & Adjusted R Square & $\begin{array}{c}\text { Std. Error of the } \\
\text { Estimates }\end{array}$ \\
\hline 1 & $.823^{\mathrm{a}}$ & .678 & .672 & .54769 \\
\hline
\end{tabular}

a. Predictors: (Constant), Behavior_Tax_Employee, Taxpaying_System, Tax_Rate

b. Dependent Variable: Individual_Taxpayer_Satisfaction

To begin, the multiple correlation coefficients $(\mathrm{R})$ of the independent variables (14 components) on the dependent variable (Individual Taxpayers' Satisfaction) are 0.823, which shows that certain factors have a favorable impact on individual taxpayers' satisfaction. In other words, the $\mathrm{R}$ square value of 0.678 indicates that the predictors and dependent variable are $67.8 \%$ correlated.

Secondly, the square multiple correlation coefficient $\left(\mathrm{R}^{2}\right)$ is .678 , indicating that the predictors or independent variables or three components or variables account for more than $67.8 \%$ of the variation or variance in the dependent variable (individual taxpayers' satisfaction). This satisfies the non-zero variance assumption since the $\mathrm{R}^{2}$ value represents the variation in the predictor values, which is not zero in this situation.

Thirdly, the adjusted $\mathrm{R}^{2}$ value of 0.672 is good for generalizing the model well because it is close to the $\mathrm{R}^{2}$ value with only a 0.006 difference $(0.678-0.672)$. If the model were applied to the entire population, it would explain 0.6 percent less variation in results.

\section{Table 5. ANOVA}

\begin{tabular}{|l|r|r|r|r|r|}
\hline Model & Sum of Squares & df & Mean Square & F & Sig. \\
\hline Regression & 77.22 & 4 & 19.31 & 205.73 & $.000 \mathrm{~b}$ \\
Residual & 37.07 & 395 & .09 & & \\
Total & 114.29 & 399 & & & \\
& & & & & \\
\hline
\end{tabular}

Predictors: (Constant), Behavior_Tax_Employee, Taxpaying_System, Tax_Rate

Dependent Variable (Individual_Taxpayers_Satisfaction)

Firstly, the F ratio is 205.73, which is extremely significant, indicating that the model increases ability to predict the outcome variable greatly. The $\mathrm{p}$ value in this table is 0.000 , which is less than 0.05 , indicating that the model fits the entire data well. As indicated by the $\mathrm{R}, \mathrm{R}^{2}$, adjusted $\mathrm{R}^{2}$, and $\mathrm{F}$ ratios, the regression model obtained a sufficient level of goodness-of-fit in 
predicting the variance of individual taxpayers' satisfaction in relation to the three components or variables.

Table 6. Summary of testing hypothesis

\begin{tabular}{|c|c|c|c|}
\hline \multirow[t]{2}{*}{ Model } & \multicolumn{2}{|c|}{ Unstandardized Coefficients } & \multirow[t]{2}{*}{ Sig. } \\
\hline & $\mathrm{B}$ & Std. Error & \\
\hline (Constant) & 0.53 & .014 & .000 \\
\hline Tax Rate & 0.38 & .04 & .000 \\
\hline Taxpaying_System & 0.24 & .04 & .000 \\
\hline Behavior_Tax_Employee & 0.16 & .03 & .000 \\
\hline
\end{tabular}

a. Dependent Variable: Individual_Taxpayer_Satisfaction

Secondly, the use of the $b$, beta values in the multiple regression model equation interprets this model to suggest that a one-unit rise in the factor tax rate affects individual taxpayers' satisfaction by 0.038 . The findings reveal that, when all other variables are held constant, there is a positive association between the elements that affect individual taxpayers' satisfaction.

Thirdly, the beta values can be used to infer the relative relevance of each predictor or component to the model because they are standardized versions of the b-values and are directly comparable. In other words, the beta coefficients might be used to explain how the three dimensions (independent variables) contribute to the variance in individual taxpayers' satisfaction (dependent variable).

In summary, it can be stated that all the underlying dimensions are positive and, therefore, are significant. Thus, the result of multiple regression analysis proved that H1: Tax rate has a positive and significant impact on individual taxpayers' satisfaction in Bangladesh.

$\mathrm{H}_{2}$ : The tax system has a positive and significant impact on individual taxpayers' satisfaction in Bangladesh.

$\mathrm{H}_{3}$ : The behavior of tax employees has a positive and significant impact on individual taxpayers' satisfaction in Bangladesh. So, there is a relationship as expected.

\section{RESULTS AND DISCUSSION}

In this regard, the main findings of this study confirmed and proved a positive relationship between the independent variables and the dependent variable. The results obtained from data in the model showed there is a direct relationship between the independent variables (tax rate, taxpaying system, and behavior of tax employees) and the dependent variable (individual taxpayers' satisfaction).

The impact of three factors on individual taxpayers' satisfaction is as follows:

- Tax Rate, positive impact, $\mathrm{P}<0.05$

- Tax System, positive impact, $\mathrm{P}<0.05$

- Behavior of Tax Employee, positive impact, $\mathrm{P}<0.05$

The study's first objective was to test a model regarding individual taxpayers' satisfaction and its predictors' influence on it. To do so, a model was developed and shows the linkages among variables, indicating a discussion to show the direction among variables. The study's 
second objective, to find out the impact of independent variables on dependent variable, was also met. The study's third objective, the relationship between positive or negative among the constructs, was also met in the study. The study's fourth objective is to provide some recommendations regarding individual taxpayers' satisfaction has also been provided in the study.

\section{POLICY IMPLICATIONS}

According to the researcher's point of view, this study carries high importance for policy implications. Individual taxpayers' are not interested in paying tax and have the tendency to show lower income in their tax file. If the tax authorities of Bangladesh provide individual taxpayers satisfaction by reducing the existing tax rate and providing rebates, besides improving the current taxpaying system and the behavior of tax employees, they will be able to collect more revenue on behalf of the government of Bangladesh. Satisfaction is a motivational term and it is a more powerful weapon than enforcing the law. In this regard, it is necessary to say that proper enforcement of tax laws is still not implemented in our country.

\section{LIMITATIONS AND FUTURE RESEARCH DIRECTION}

The study is not free from flaws. Mentionable flaws of the study are: (1) the data collection was based on the entire city, so distance is an obstacle to collecting data from different individual taxpayers'. (2) The data collected through a face-to-face survey questionnaire was very timeconsuming. (3) The budget limitation was a major obstacle to this research because it was completed through the researcher's own fund.

A few questions have arisen in the mind of the researcher during this research work, but there is no scope to include them in the study. It is recommended for future study by other researchers. Those questions involve: (1) Future research may include new factors if it is supported by its country's context (2) This study was a paper-based survey. The country which is advanced in internet use can do research through an internet-based survey because more respondents' opinions are possible to collect for generalization of the results.

\section{CONCLUSION}

The focus of the government's revenue department is to collect taxes from the relevant taxpayers' and the performance of the department depends on how smoothly they have achieved the targeted revenue. The law itself is not enough to collect taxes from taxpayers'. The study found out taxpayers' satisfaction is also necessary and, in this regard, necessary constructs and their scales have been presented in the study. The NBR and policy makers of tax should focus on taxpayers' satisfaction besides other policy and strategy.

\section{REFERENCES}

Adeyemi, A. (2013). Assessing the Effects of Taxation System on Nigerian Economic Growth. In Proceedings of 2013 International Conference on Poverty Alleviation Income Redistribution \& Rural Development in Developing Countries.

Besley, T., \& Persson, T. (2013). Taxation and development. In Handbook of public economics (Vol. 5, pp. 51-110). Elsevier. 
Cerny, B. A., \& Kaiser, H. F. (1977). A Study of a Measure of Sampling Adequacy for FactorAnalytic Correlation Matrices. Multivariate Behavioral Research, 12(1), 43-47.

Carnahan, M. (2015). Taxation Challenges for Developing Countries. Asia and the Pacific Policy Studies, 2(1), 169-182.

Deyganto, K. (2018). Factors Influencing Taxpayers' Voluntary Compliance Attitude with Tax System: Evidence from Gedeo Zone of Southern Ethiopia. Universal Journal of Accounting and Finance, 6(3), 92-107.

Ibrahim, M., Musah, A., \& Abdul, H. A. (2015). Beyond Enforcement: What Drives Tax Morale in Ghana? Humanomics, 31(4), 399-414. https://doi.org/10.1108/H-04-2015-0023

Luthans, F. (2002). The need for and meaning of positive organizational behavior. Journal of Organizational Behavior, 23, 695-706.

Mahmood, M. (2018). The Tax Regime in Bangladesh: Issues in Expanding the Tax Base. The Financial Express. Retrieved from https://www.thefinancialexpress.com.bd/views/thetax-regime-in-bangladesh-issues-in-expanding-the-tax-base-1526745339

Padovano, F., \& Galli, E. (2001). Tax Rates and Economic Growth in the OECD Countries (1950-1990). Economic Inquiry, 39, 44 - 57 (January).

Palil, M. (2010). Tax Knowledge and Tax Compliance Determinants in Self-Assessment System in Malaysia. Retrieved from https://core.ac.uk/download/pdf/76107.pdf

Wright, T. A. (2003). Positive Organizational Behavior: An Idea whose Time has Truly Come. Journal of Organizational Behavior, 24, 437-442.

\section{Copyrights}

Copyright for this article is retained by the author(s), with first publication rights granted to the journal. This is an open-access article distributed under the terms and conditions of the Creative Commons Attribution license (http://creativecommons.org/licenses/by/4.0/) 